\title{
Assessment of Proximate Composition of Wild Forages Under the Influence of Seasonal and Spatial Variations in Semi-arid Region
}

\author{
HUMAYUN BASHIR ${ }^{1,2}$, KAFEEL AHMAD ${ }^{1}$, ZAFAR IQBAL KHAN ${ }^{1}$, SONAINA NAZAR ${ }^{1}$, \\ SHEHZADI MAHPARA ${ }^{3}$, MUHAMMAD SOHAIL ${ }^{1}$, JAWAHER ALKAHTANI ${ }^{4 *}$, \\ LATIFAH ABDULRAHMAN ALHUMAID ${ }^{4}$, MANAL M. AL SHAQHAA ${ }^{4}$, \\ MOHAMED SOLIMAN ELSHIKH ${ }^{4}$ \\ ${ }^{1}$ Department of Botany, University of Sargodha, Sargodha, Pakistan \\ ${ }^{2}$ Institute of Molecular Biology and Biotechnology, The University of Lahore, Lahore, Pakistan \\ ${ }^{3}$ Department of Plant Beeding and Genetic Sciences, Ghazi University, Dera Ghazi Khan, Pakistan \\ ${ }^{4}$ Department of Botany and Microbiology, College of Science, King Saud University, Riyadh, 11451, Saudi Arabia
}

\begin{abstract}
The effect of spatio-temporal variations in proximate composition of the forages and fodder species grazed by the ruminants in different sites of district Bhakkar, Pakistan was evaluated. Samples were collected from different sites of the selected region during four seasons. There was significant effect of site on all proximate parameters except ether extract. Season of collection significantly affected moisture content, dry matter, crude protein, crude fiber, ether extract, NFES and net energy while ash content was non-significantly affected. Site $x$ season also has significant effect on all proximate parameters. The study unveils the composition of diet of ruminants, providing information about the need of supplementation for these animals to increase their productivity.
\end{abstract}

Keywords: proximate, forages, grazers

\section{Introduction}

The nutritional significance of forage is a product of proximate composition of the plant material, its digestibility and the bioavailability of the nutrients present in it by Sher et al. [1]. Proximate analysis gives the detailed information regarding the composition of sample. The analysis gives basic information about ash content, moisture content, volatile matter content and fixed carbon. The charring of organic components leaves behind the dry inorganic residue known as ash. Ash content is the measurement of mineral content of the sample. The low volatility of minerals ensures their safety during burning of sample [2]. High ash value is the indication of higher mineral content in the plant sample. The mass of ash produced is variable according to the part of plant charred and the age of plant by Vermani et al. [3]. The moisture content is conditional on temperature, climatic conditions, humidity, storage conditions and harvest time of the plant. Moisture content determines the stability of plant based drugs and formulations. Lower the moisture content, higher is the stability of the drug. The lower moisture level is also an indication of high caloric value of plant samples by Nair et al. [4].

The chemical composition of plant, particularly its crude protein content, is responsible for the digestibility in animal's gut by Sher et al. [1]. Inverse relation exists between the palatability and crude fiber content of the plant. Good quality forage thus contains less concentration of fibers and is rich in proteins by Sher et al. [5]. Fiber concentration drops the forage quality by dilution of available nutrients, thereby lowering the digestibility of plant material by Jimoh et al. [6]. The maceration of food and expulsion of waste material from the gastrointestinal tract is closely associated with the concentration of crude fibers in the diet. Food containing high value of fibers is helpful for treating constipation. The treatment of hypertension, colon and breast cancer, type 2 diabetes and coronary heart diseases is also accredited to crude fibers [7].

\footnotetext{
*email: jsalqahtani@ksu.edu.sa
} 
The feasibility of a plant to be used as forage is directly dependent upon the accumulation of carbohydrates and proteins in different parts of the plant by Esene et al. [8]. The concentration of carbohydrates could be derived by treatment of crude fiber with acid and alkali by Vidita et al. [9]. Carbohydrates are a ready source of energy for living systems. Storage compounds such as starch and glycogen belong to polysaccharide class of carbohydrates and provide a fair amount of energy on oxidation by Hasan et al. [10]. The optimum daily intake dietary of carbohydrates for children, adults, feeding and pregnant females is 130, 130, 175 and $210 \mathrm{~g} /$ day and that of proteins is 13-19, 34-56 and 17-71 respectively [11]. Plant proteins are cheap to produce and more convenient to store and transport in comparison with the flesh proteins but the nuisance associated with plant proteins is their affixation with anti-nutrient compounds which make them unpalatable [12]. Above literature exhibits the requirement of unveiling the seasonal effects on proximate composition of forages and fodders in semi-arid environment, which has not been yet highlighted comprehensively. Current work was done to evaluate the seasonal variation on proximate contents and to check its toxicity in every season.

\section{Materials and methods Study site}

The present investigation was conducted at two sites of (Tehsil Bhakkar and Tehsil Darya Khan) District Bhakkar, Pakisatn having average annual temperature $24.6^{\circ} \mathrm{C}$ and average rainfall $213 \mathrm{~mm}$. Both of these sites were further divided into 10 plots for the collection of samples.

\section{Collection of samples}

The forage and fodder species available in the study site were randomly collected in four seasons [(S1) Summer, (S2) Winter, (S3) Autumn and (S4) Spring] using sterilized apparatus. The samples were rinsed with distilled water to wash off any dust or impurities. The collected samples were then shade dried, stored in labeled seal bags and placed in incubator for 5 days at $70^{\circ} \mathrm{C}$ ) [13]. Dried samples were combined into one composite sample and used for analysis. List of the collected plants is given below (Table 1).

Table 1. List of forages with scientific and local names

\begin{tabular}{|c|c|c|c|c|c|c|c|c|}
\hline $\begin{array}{l}\text { Sr. } \\
\text { No }\end{array}$ & Summer Plants & $\begin{array}{l}\text { Local } \\
\text { Names }\end{array}$ & Autumn & $\begin{array}{l}\text { Local } \\
\text { Names }\end{array}$ & Winter Plants & Local Names & Spring & $\begin{array}{l}\text { Local } \\
\text { Names }\end{array}$ \\
\hline 1 & Peganum harmala & Hermal & $\begin{array}{l}\text { Cymbopogon } \\
\text { jwarancusa }\end{array}$ & Khawi & $\begin{array}{l}\text { Convolvulus } \\
\text { anvensis L. }\end{array}$ & $\begin{array}{l}\text { Lehli, } \\
\text { Wanvehri }\end{array}$ & Calotropis procera & $\mathrm{Akk}$ \\
\hline 2 & $\begin{array}{l}\text { Cymbopogon } \\
\text { jwarancusa }\end{array}$ & Khawi & $\begin{array}{l}\text { Calotropis } \\
\text { procera }\end{array}$ & Alkk & $\begin{array}{l}\text { Chenopodium } \\
\text { album L. }\end{array}$ & Bathu & $\begin{array}{l}\text { Cymbopogon } \\
\text { jwarancusa }\end{array}$ & Khawi \\
\hline 3 & $\begin{array}{l}\text { Cucumis melo var. } \\
\text { Agrestis }\end{array}$ & Chibber & $\begin{array}{l}\text { Ziziphus } \\
\text { mauritiana }\end{array}$ & Bairi & $\begin{array}{l}\text { Parthenium } \\
\text { hysterophorus }\end{array}$ & Gajar Boti, & Ziziphus mauritiana & Bairi \\
\hline 4 & Calotropis procera & Alkk & $\begin{array}{l}\text { Citrullus } \\
\text { colocynthis }\end{array}$ & Tumma & Cyperus ivia & Bhoian & $\begin{array}{l}\text { Cucumis melo var. } \\
\text { Agrestis }\end{array}$ & Chibber \\
\hline 5 & Tribulus terrestris & Bhakra & $\begin{array}{l}\text { Tribulus } \\
\text { terrestris }\end{array}$ & Bhakra & $\begin{array}{l}\text { Euphorbia } \\
\text { prostrata }\end{array}$ & Dhodak & Prosopis juliflora & $\begin{array}{l}\text { Jangli } \\
\text { Kikkar }\end{array}$ \\
\hline 6 & Citrullus colocynthis & Tumma & $\begin{array}{l}\text { Peganum } \\
\text { harmala }\end{array}$ & Hermal & $\begin{array}{l}\text { Fimbristylis } \\
\text { dichotoma }\end{array}$ & Choti Bhoian & Medicago sativa & Lucem \\
\hline 7 & Achyranthes aspera $\mathrm{L}$. & $\begin{array}{l}\text { Puth } \\
\text { Kanda }\end{array}$ & Zsa majs & Makai & $\begin{array}{l}\text { Digitaria } \\
\text { saneuinalis }\end{array}$ & $\begin{array}{l}\text { Mooti Khabbal, } \\
\text { karabara }\end{array}$ & $\begin{array}{l}\text { Trifolium } \\
\text { alexandrinum }\end{array}$ & Barseem \\
\hline 8 & Zisiphus mauritiana & Bairi & $\begin{array}{l}\text { Sorghion } \\
\text { bicolor }\end{array}$ & Jowvar & $\begin{array}{l}\text { Ziriphus } \\
\text { mauritiana }\end{array}$ & Bair & Hordeum vulgare & Jao \\
\hline 9 & Prosopis juliflora & $\begin{array}{l}\text { Jangli } \\
\text { Kilkkar }\end{array}$ & $\begin{array}{l}\text { Prosopis } \\
\text { juliflora }\end{array}$ & $\begin{array}{l}\text { Jangli } \\
\text { Kilkkar }\end{array}$ & $\begin{array}{l}\text { Prosopis } \\
\text { juliflora }\end{array}$ & Jangli Kikkar & Zsa mays & Makai \\
\hline 10 & Pennisetum glaucum & Bajra & & & $\begin{array}{l}\text { Medicago } \\
\text { sativa }\end{array}$ & Lucem & Cicer arietinum & Channa \\
\hline $11 \overline{1}^{-}$ & Zsa mays & Makai & & & $\begin{array}{l}\text { Trifolium } \\
\text { alexandrinum }\end{array}$ & Barseem & & \\
\hline 12 & Sorghum bicolor & Jowar & & & Avena sativa & $\mathrm{Jai}$ & & \\
\hline 13 & $\begin{array}{l}\text { Cyamopsis } \\
\text { tetragonoloba }\end{array}$ & Guar & & & $\begin{array}{l}\text { Hordeum } \\
\text { vulgare }\end{array}$ & Jau & & \\
\hline 14 & Sesbania sesban & Jantar & & & Brassica nigra & Rai & & \\
\hline 15 & & & & & $\begin{array}{l}\text { Brassica } \\
\text { campestris }\end{array}$ & Sarson & & \\
\hline 16 & & & & & $\begin{array}{l}\text { Cicer } \\
\text { arietinum }\end{array}$ & Channa & & \\
\hline
\end{tabular}




\section{Proximate analysis}

The protocols designed by Association of Official Analytical Chemists [14] were followed for the accomplishment of proximate analysis of the plant material. Proximate analysis gives the detail about dry matter, moisture content, crude protein, crude fibers, ash, ether extract NFES (Nitrogen free extractable substances) and net energy.

\section{Statistical analysis}

Data visualization was performed with the help of bar plots using ggplot2 package in software R. Analysis of variance (ANOVA) by Steel et al. [15] along with least significant difference (LSD) test was applied using Statistix 8.1.

\section{Results and discussions}

\section{Ash}

The analysis of variance of data for Ash showed significant variations in site and site $\mathrm{x}$ season but non-significant variations in seasons (Table 2). Ash content in forages varied from 20.94 to $23.50 \%$ in all seasons at both sites. Lowest ash content was observed in season 1 at site 1 and highest ash content was observed in season 4 at site 2 (Figure 1). The ash content of forages as reported in the present study were higher as compared to the values reported by Tsoukala et al. and Ahmad et al. $[16,17]$ and lower in comparison with the findings of Qayyum et al. [18].

Table 2. Analysis of variance of proximate contents for forages mean square of studied parameters at two sites during four seasons with 482 error degree of freedom

\begin{tabular}{|c|c|c|c|c|}
\hline Parameter & Site & Season & Site x Season & Error \\
\hline Ash (\%) & $113.88^{* * *}$ & $10.59 \mathrm{~ns}$ & $39.45^{* * *}$ & 4.917 \\
\hline M. C. (\%) & $116.10^{* * 8}$ & $56.36^{* * *}$ & $63.85^{* * * *}$ & 1.86 \\
\hline Dry matter (\%) & $121.38^{* * *}$ & $59.64^{* * *}$ & $75.35^{* * * *}$ & 2.32 \\
\hline C. Protein (\%) & $116.26^{* * *}$ & $31.98^{* * *}$ & $44.19^{* * * *}$ & 2.93 \\
\hline C. Fiber (\%) & $113.73^{* * *}$ & $51.27^{* * *}$ & $43.32^{* * *}$ & 1.13 \\
\hline E. E. (\%) & $0.00 \mathrm{~ns}$ & $2.47^{* * *}$ & $2.30^{* * * *}$ & 0.03 \\
\hline NFES & $1032.91^{* * *}$ & $307.37^{* * *}$ & $434.19^{* * * *}$ & 13.132 \\
\hline Net Energy & $124.61^{*}$ & $339.73^{* * *}$ & $321.47^{* * * *}$ & 27.7387 \\
\hline
\end{tabular}

Environmental and genetic factors pivotally explain the presence of mineral and ash contents of forages and fodders [19] playing important role in the morphological and physiological functions of plants. Availability of ash content varies among different organs of the same plant, being highest in the leaves by Monti et al. [20]. Quality of biomass affects the net energy and ash content of plants and often causes reduction in the heating value. Seasonal variations and plant species also affect the ash content in available plant. Ash content and heating values show inverse relationship, high ash content causing reduction of heating value. 1 percent increase of ash content causes $0.2 \mathrm{MJ} \mathrm{kg}^{-1}$ decline in heating value by Cassida et al. [21]. 


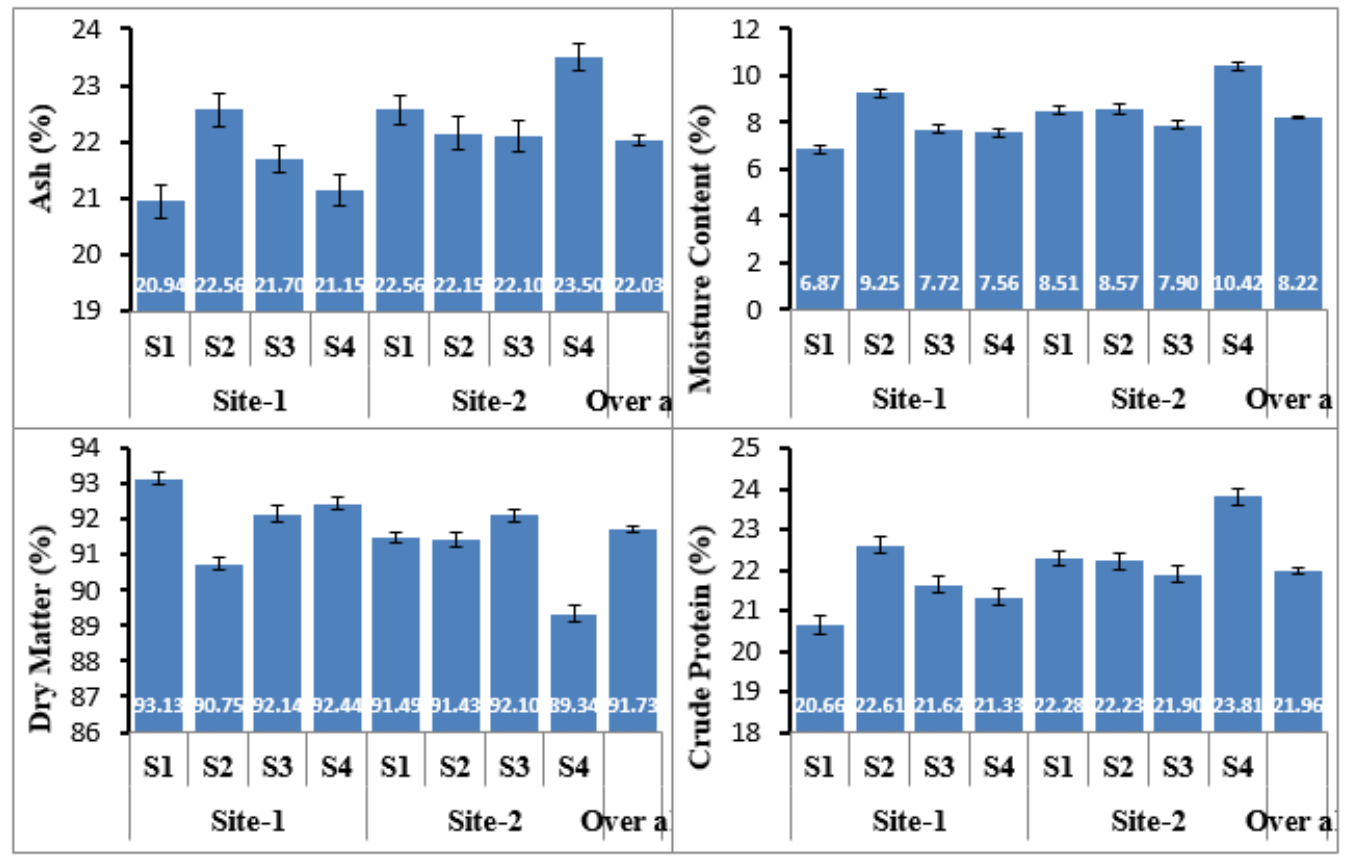

Figure 1. Mean concentrations of ash, moisture content, dry matter and crude protein in four seasons at two sites

\section{Moisture content}

Variance analysis of Moisture content in forages exhibited significant effect of site, season and site $\mathrm{x}$ season (Table 2). Moisture content in forages ranged from 6.87 to $10.42 \%$ at both sites in all seasons. Minimum value of moisture content was present at site 1 in season 1 and maximum value of Moisture content was present at site 2 in season 4 (Figure 1). Present findings of Moisture content were similar to the findings of Owolabi et al. [22]. Moisture values reported in the current investigation were lower than the values described by Aurelia et al and Tsoukala et al [23,24].

Moisture content affects the plants and animal in many ways. In plants, it is considered essential for many functions and growth of plants. Plants need water not only for growth but as a key factor to perform many functions and survival of plant. Importance of moisture content increases 100 times in arid environment, so plants growing in such conditions adapt many modifications to survive in their environment and to save moisture content. These adaptations include development of thick cuticle, small leave size, spines and succulent [25]. Moisture content also affects nutritional value of animal feed. Animal feed consist of many nutrient e.g. vitamins, fats, proteins, water, minerals and carbohydrates. Moisture content also affects the nutritional properties of feeds during conversion of nutrients into dry matter [26] and Ahmad et al. [27].

\section{Dry matter}

Analysis of data for forages revealed that site, season and site $\mathrm{x}$ season had significant effect on Dry matter concentration (Table 2). Concentration of Dry matter at both sites in all seasons varied from 89.33 to $93.12 \%$. Lowest level of Dry matter was observed in season 4 at site 2 and highest level was observed in season 1 at site 1 (Figure 1). Current analysis of forages showed that Dry matter contents were higher than the values analyzed by Mutayoba et al and Bolanle and Adedayo [28,29]. Present values of dry matter were lower than the values mentioned [30].

Dry matter is actual indication of nutrients in plants and feed after removal of water. Study on Dry matter, nutrient uptake and nutrient mobility gives proper information about the requirement of optimization of fertilizer and reduction of nutrient loss [31]. Dry matter is known as important parameter in plants as it is associated with several aspects of plant survival and growth. Dry matter also plays significant role in explaining ecological behavior and relative growth of plants by Garnier et al. [32]. 
Yield of crops has positive relation with accumulation of nutrient and production of Dry Matter. High amount of dry matter causes to increase the yield of crops while low dry matter reduces the crop yield. Accumulation of Dry matter in plants is associated with stage of plant growth. Dry matter contents increases as the growth of plants increase by Meng et al. [33].

\section{Crude protein}

Results of analysis of variance showed that crude protein had significant variations in site, season and site $\mathrm{x}$ season (Table 2). Crude protein values throughout all season at both sites varied from 20.65 to $23.81 \%$. Minimum value of Crude protein was showed in season 1 at site 1 and maximum crude protein was showed in season 4 at site 2 (Figure 1). Crude protein contents of forages were higher than the contents of crude protein examined [29]. Owolabi et al., [22] indicated lower level crude protein than the level revealed in the present study. Findings of [34] were much lower than the current findings of protein.

Crude protein is known as most vital factor that describes the quality of produced forage and fodders. Crude protein level in forages of grassland and rangelands has more significant effect upon consumers by Mlay et al. [35]. Crude protein content in grassland plants is higher at early growth stages and the level starts falling as age of plant increases so plants at early growth stages are rich source of crude protein by Hejcman et al. [36]. Crude protein level also varies according to plants organ. Leaves of plant contain high crude protein level than shoots and stem. Leaves also possess high crude protein level at mature stage of plant. Crude protein content also varies according to plant types. Legumes have high crude protein than grasses and forbs exist between legumes and grasses [37].

\section{Crude fiber}

Analysis of variance of data regarding crude fiber showed significant effects in site, season and site $\mathrm{x}$ season (Table 2). Crude fiber contents in forages ranged from 16.61 to $19.81 \%$ at both sites of all seasons. Lowest level of Crude fiber was available in season 1 at site 1 and highest level was available in season 4 at site 2 (Figure 2). Present investigation showed that crude fiber concentration of forages was lower as compared to the concentrations given by [38,34]. Crude fiber contents of present work were higher than the work [29].

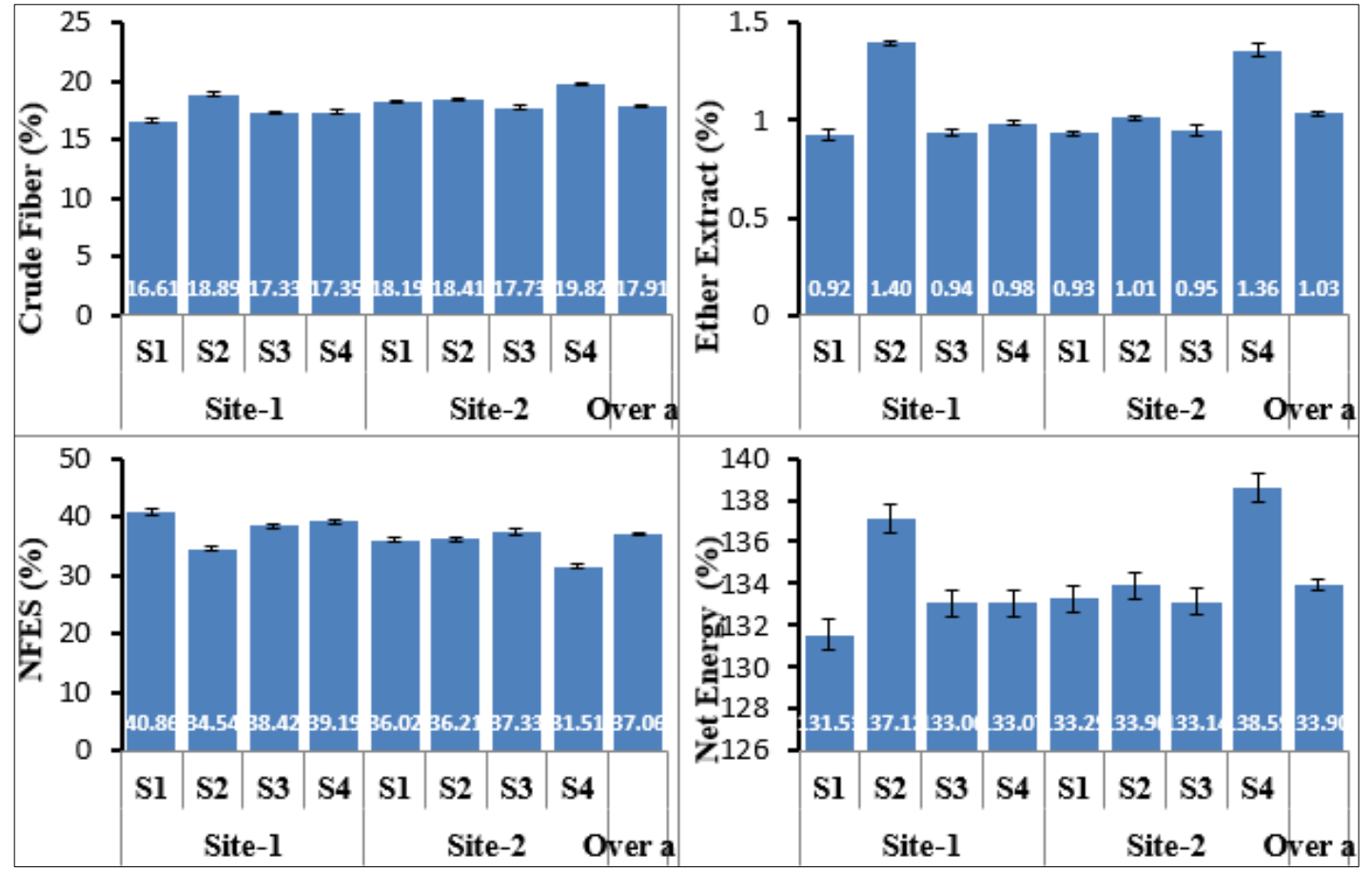

Figure 2. Mean concentrations of crude fiber, ether extract, NFES and net energy in four seasons at two sites 
Crude fiber is known as permanent feed from plant origin. It is composed of many components like pectin substances, waxes, gums, indigestible oligosaccharides, cellulose, hemicelluloses and lignin. Digestion of Crude fiber is very complex, it is considered non-digestible because it is digested to lesser or greater extent in the gastrointestinal tract of animals by enzymes of the microfauna. It also shows its specific effects in animal after binding to minerals and organic substances in gastrointestinal tract by Pisarikova et al. [39]. Crude fibers may be soluble or insoluble, depending upon the ability of hemicellulose, pectin and cellulose to bind water. In animals, fibers promote peristalsis by inducing mechanical sensation of glutting and it also plays significant role in the regulatory activity of rumen [40].

\section{Ether extract}

The analysis of variance of data for Ether extract depicted significant variations in season and site $\mathrm{x}$ season and non-significant variations in sites (Table 2). Results of Ether extract varied from 0.92 to 1.39 $\%$ at both sites in all seasons. Minimum value of Ether extract was available in season 1 at site 1 and maximum value was available in season 2 at site 1 (Figure 2). Findings of Dash et al. [41] were much lower than current findings of Ether Extract contents. Ether Extract values described in present research were lower than the ether extract examined by Ahmad et al and Chatterjee and Chatterjee $[42,43]$.

Role of ether extract or total fat in plants and consuming animals is very important. It contains the group of nutrient fat which play significant role in body of animals [44]. It is also considered as an essential energy source of ruminant diet. Level of ether extract generally remains very low and its level decrease as the age of plant increase [45]. Leaves possesses high amount of ether extract as compared to other plant parts. Plant species, phenological stage and rate of grazing also affect the level of ether extract in plants as well as in animals by Cabiddu et al. [46].

\section{Nitrogen free extractable substances (NFES)}

NFES values revealed significant variations in site, season and site $\mathrm{x}$ season (Table 2). Value of NFES was ranged from 31.50 to $40.86 \%$ at all sites in all seasons. Minimum level of NFES was observed in season 4 at site 2 and maximum level was observed in season 1 at site 1 (Figure 2). Current available contents of NFES were lower as compared to the findings of Cruz-Suarez et al. [47]. Present investigation showed that NFES contents available in forages were similar to the NFES studied by Ahmad et al. [48].

Concentration of NFES shows reduction with excessive use of fertilizers. On the other hand NFES level increase as grasses mature. NFES level also increases in summer season because low moisture also affect the NFES level which has direct relation with maturity of grasses [49]. Deficiency of nitrogen in soil and plant tissue also causes elevation of NFES level. NFES level also affect the food energy of seed as high NFES level inverse the seed food energy by Bashir et al. [50].

\section{Net energy}

Analysis of variance of data for Net energy in forages exhibited significant effects of site, season and site $x$ season (Table 2). Net energy contents in all seasons at both sites varied from 131.52 to $138.58 \%$. Lowest value of Net energy was present in season 1 at site 1 and highest value of Net energy was present in season 4 at site 2 (Figure 2). Net energy level described in forages of present work was higher from the work of Castell et al. [51]. Bashir et al., [50] also examined net energy contents but the reported values were lower than the current energy contents. Present findings of Net energy were higher than the early findings of Hussain et al. [52].

Net energy value is considered as most important source of energy for ruminants. Net energy is like a fuel for animals. Net energy is basically inherent chemical energy which comes from carbo-hydrates, fat and protein of organic food compounds by Bhattacharjee et al. [53]. Proper evaluation and formulation of feed requires accurate amount of net energy of forages ingested by animals. Net energy value is the main factor which determines different changes in body condition e.g. milk production and 
fetal growth and body weight of animal by Johnson et al. [54]. Current net energy results were enough to fulfill ruminant requirements and it was possible only due to availability of rich nutrient forages and diet.

\section{Conclusions}

Assessment of proximate composition of the forages shows variations with respect to site and seasons. Site 2 exhibited rich composition except for dry matter and NFES which were high in site 1. Highest concentration of ash, moisture, crude proteins, crude fiber, ether extract and net energy was present in Spring at site 2 while lowest concentration occurred in Summer at site 1. Thus, supplementation during summer season is particularly suggested for the ruminants residing at site 1 .

Acknowledgement. This work was supported by The Higher Education Commission, Pakistan through a research project no. 20-3546/NRPU/R\&D/HEC/14/536. We are also thankful to local farmers of study area for providing every possible support in collection of samples. The authors also gratefully acknowledge the Deanship of Scientific Research at King Saud University for funding this work through the research group no. (RG-1441-329).

\section{References}

1.SHER, A., ANSAR, M., MANAF, A., QAYYUM, A., SAEED, M. F., IRFAN, M., (2014). Hydrocyanic acid and sugar content dynamics under nitrogen and sulphur application to forage sorghum cultivars. Turk. J. Field Crops., 19(1): 46-52

2. SUNGGYU, L., (2005). Encyclopedia of chemical processing. Edn 3, CRC Press, 1: 31-33

3.VERMANI, A., NAVNEET, P., CHAUHAN, A., (2010). Physico-chemical analysis of ash of Some medicinal plants growing in Uttarakhand, India. Nat. Sci., 8(6): 88-91

4.NAIR, L.D., SAR, S. K., ARUN, A., DEEPAK, M., (2012). A Comparative study on Proximate Analysis conducted on Medicinal Plants of Chhattisgarh, CG, India, Res. J. Chem. Sci., 2(9): 18-21

5.SHER, A., ANSAR, M., IJAZ, M., SATTAR, A. (2016). Proximate analysis of forage sorghum cultivars with different doses of nitrogen and seed rate. Turk. J. Fiel. Crop., 21(2): 276-285

6. JIMOH, S. O., OLANITE, J. A., MUSTAPHA, S. O., OLADEPO, O., AMISU, A. A., SOTIMEHIN, O. A., (2015). Proximate composition of the morphological fractions of panicum maximum varieties as affected by age in the derived savanna of Nigeria. 1st Biennial Conference: society for grassland research and development in Nigeria. Dec. 6-9, 2015, Federal Univ. of Agric. Abeokuta, Nigeria: 8385

7. VADIVEL, V., JANARDHANAN, K., (2005). Nutritional and antinutritional charecteristis of seven south Indian wild legumes. Plant. Fd. Hum. Nutr., 60: 69-75

8. ESENE, O., UCHECHUKWU, R., HUSSEINI, S. J., ASUQUO, T. S., (2011) Proximate and phytochemical analysis of leaf, stem and root of Eugenia uniflora [Surinam or Pitanga cherry]. J. Nat. Prod. Plant Res., 1: 1-4

9. VIDITA, V. B., SALUJA, A. K., DHOLWANI, K. K., (2013) Detection of heavy metal contents and proximate analysis of roots of Anogeissus latifolia. J. Pharmac. Phytochem., 1: 61-65

10.HASAN, A. B., KABIR, S., REZA, A. S., ZAMAN, M. N., AHSAN, A., RASHID, M., (2013). Enrichment factor and geo-accumulation index of trace metals in sediments of the ship breaking area of Sitakund Upazilla (Bhatiary-Kumira), Chittagong, Bangladesh. J. Geochem. Explor., 125: 130-137 11.***FND (Food and Nutrition Division). 2002. Dietary reference intake for energy, carbohydrate, fibre, fat, fatty acids, cholesterol, protein and amino acid (micro-nutrients). Food and Nutrition Board, Institute of medicine. National Academy of Sciences. pp. 1

12. SINGH, V., MOHANTY, C. S., (2014). Effort towards reducing the antinutrients in legumes through the application of genomic technologies. In: Biotechnology Volume 5: Gene and Protein Engineering, Stadium Press, LLC, India: pp. 1 
13.SANCHEZ, P. A., (1976). Properties and management of soils in the tropics. John Wiley and Sons, New York: pp. 1

14.***Association of official analytical chemists (AOAC). (2006). Official Methods of Analysis. 18th Edition, Gaithersburgs, MD: pp. 1

15.STEEL, R. G. D., TORRIE, J. H., DICKEY, D. A., (2006). Principles and procedures of statistics. A biometrical approach. 3rd Edition of McGraw Hill Company, New York, USA

16. TSOUKALA, A., PAPALAMPROU, E., MAKRI, E., DOXASTAKIS, G., BRAUDO, E. E., (2006). Adsorption at the air water interface and emulsification properties of grain legume protein derivatives from pea and broad bean. Colloid. Surfac. Biointer., 53: 203-208

17.AHMAD, K., SHAHEEN, M., MIRZAEI, F., KHAN, Z. I., GONDAL, S., FARDOUS, A., HUSSAIN, A., ARSHAD, F., MEHMOOD, T., (2013). Proximate analysis: relative feed values of various forage plants for ruminants investigated in a semi-arid region of Punjab. Pak. Agric. Sci., 4(6): 302-308

18.QAYYUM, M. M. N., BUTT, M. S., ANJUM, F. M., NAWAZ, H., (2012). Composition analysis of some selected legumes for protein isolated recovery. J. Anim. Plant Sci., 22(4): 1156-1162

19. CASLER, M. D., BOE, A. R., (2003). Cultivar x environment interactions in switchgrass. Crop Sci., 43: 2226-2233

20. MONTI, A., VENTURI, G., AMADUCCI, M. T., (2005). Biomass potentials and ash content of switchgrass, giant reed and cardoon in northern Italy. Proc. 14th European Biomass Conference \& Exhibition. Biomass for Energy, Industry and Climate Protection. Paris: 261-263

21. CASSIDA, K. A., MUIR, J. P., HUSSEY, M. A., READ, J. C., VENUTO, B. C., OCUMPAUGH, W. R., (2005). Biofuel Component Concentrations and Yields of Switchgrass in South Central U.S. Environments. Crop Sci., 45: 682-692

22. OWOLABI, A. O., NDIDI, U. S., JAMES, B. D., AMUNE, F. A., (2012). Proximate, antinutrient and mineral composition of five varieties (improved and local) of cowpea (Vigna unguiculata) commonly consumed in samaru community, Zaria-Nigeria. Asian J. Food Sci. Tech., 4: 70-72

23. AUREliA, I., IULIANA, A., AURA, D., GABRIELA, G., CRISTINA, B., ANDREI, N., (2009). Chemical and functional characterization of chickpea protein derivates. The Annals of the University of Dunarea de Jos of Galati. Fas. VI. Fd. Tech., 33: 16

24. TSOUKALA, A., PAPALAMPROU, E., MAKRI, E., DOXASTAKIS, G., BRAUDO, E. E., (2006). Adsorption at the air water interface and emulsification properties of grain legume protein derivatives from pea and broad bean. Colloid. Surfac. Biointer., 53: 203-208

25. RABAS, A. R., MARTIN, C. E., (2003). Movement of water from old to young leaves in three species of succulents. Ann. Bot., 92(4): 529-536

26. THIEX, N., RICHARDSON, C. R., (2003). Challenges in measuring moisture content of feeds. $J$. Anim. Sci., 81: 3255-3266

27. AHN, J. Y., KIL, D. Y., KONG, C., KIM, B. G., (2014). Comparison of oven-drying methods for determination of moisture content in feed ingredients. Asian-Aus. J. Anim. Sci., 27(11): 1615-1622

28.MUTAYOBA, S. K., DIERENFELD, E. MERCEDES, V. A., FRANCES Y., KNIGHT, C. D., (2011). Determination of chemical composition and anti-nutritive components for Tanzanian locally available poultry feed ingredients. Int. J. Poul. Sci., 10(5): 350-357

29. BOLANLE, A. O., ADEDAYO, A., (2012). Comparative study on chemical compositions, phytochemical screening and physico-chemical properties of the seeds of Dioclea reflexa. Ultra Chem., 8(2): 251-264

30. OGBE, A. O., AFFIKU, J. P., (2012). Proximate Study, mineral and anti-nutrient composition of (Moringa oleifera) leaves harvested from Lafia, Nigeria: potential benefits in poultry nutrition and healt. J. Microbio. Biotech. Food Sci., 1: 296-308

31. MOUSTAKAS, N. K., NTZANIS, H., (2005). Dry matter accumulation and nutrient uptake in fluecured tobacco (Nicotiana tabacum L.). Fiel. Crop. Res., 94: 1-13 
32. GARNIER, E., SHIPLEY, B., ROUMET, C., LAURENT, G., (2001). A standardized protocol for the determination of specific leaf area and leaf dry matter content. Functin. Eco., 15(5): 688-695

33. MENG, Q., YUE, S., CHEN, X., CUI, Z., YE, Y., MA, W., TONG, Y., ZHANG, F., (2013). Understanding dry matter and nitrogen accumulation with time- course for high-yielding wheat production in China. Plos. One., 8(7): 1-7

34. ABEROUMAND, A., (2011). Assessment of Proximate and Phytochemical Composition for Evaluation of Nutritive Values of Some Plant Foods Obtained from Iran and India. In Res. in Org. Farm., InTech: pp. 1

35. MLAY, P.S., PEREKA, A., CHIKULA PHIRI, E., BALTHAZARY, S., IGUSTI, J., HVELPLUND, T., RIIS WEISBJERG, M., MADSEN, J., (2006). Feed value of selected tropical grasses, legumes and concentrates. Veterin. Arhiv., 76(1): 53-63

36. HEJCMAN, M., SZAKOVÁ, J., SCHELLBERG, J., TLUSTOŠ, P., (2010). The Rengen Grassland Experiment: relationship between soil and biomass chemical properties, amount of elements applied, and their uptake. Plan. and soil., 333(1-2), 163-179

37. GANSKOPP, D., BOHNERT, D., (2001). Nutritional dynamics of northern Great Basin grasses. $J$. Range Manage., 54: 640-647

38. SINGH, G. (2004). Practical Manual of Biochemistry, 5th ed. CBS Publishers, New Delhi: pp. 1 39. PISARIKOVA, B., LEKARSTVI, V.U.V., PETERKA, J., TRCKOVA, M., LEKARSTVI, V.U.V., MOUDRY, J., ZRALY, Z., LEKARSTVI, V.U.V., HERZIG, I., LEKARSTVI, V.U.V., (2007). The content of insoluble fibre and crude protein value of the aboveground biomass of Amaranthus cruentus and A. hypochondriacus. Czech J. Anim. Sci. UZPI (Czech Republic)., 10: 348-353

40. KALAC, P., MIKA, V., (1997). Natural harmful substances in vegetable fodder. UZPI, Prague, pp. 317

41. DASH, A. K., DUTTA, G. K., SAHOO, G., MISHRA, S. K., SARDAR, K. K., BISOI, P. C., (2012). Phytochemical screening, mineral and proximate composition of Asteracantha longifolia leaf extracts as a quality livestock feed. J. Med. Plants Res., 6(21): 3786-3792

42. AHMAD, K., SHAHEEN, M., MIRZAEI, F., KHAN, Z. I., GONDAL, S., FARDOUS, A., HUSSAIN, A., ARSHAD, F., MEHMOOD, T., (2013). Proximate analysis: relative feed values of various forage plants for ruminants investigated in a semi-arid region of Punjab. Pak. Agric. Sci., 4(6): 302-308

43. CHATTERJEE, A., CHATTERJEE, S., (2012). Proximate analysis, phyto-chemical screening and Anti-inflammatory activity of Coccinia indica. Int. J. Pharm. Chem. Bio. Sci., 2(3): 299-304

44. LIAMADIS, L. G. (2000). Physiology of the nutritional deficiencies of an animal body, University Studio Press Publications, Thessaloniki. 1: 1-5

45. BRUINENBERG, M. H. (2003). Forages from intensively managed and semi-natural grasslands in the diet of dairy cows. PhD Thesis Wageningen University, Wageningen, The Netherlands: pp. 173

46. CABIDDU, A., DECANDIA, M., ADDIS, M., PIREDDA, G., PIRISI, A., MOLLE, G., (2005). Managing mediterranean pastures in order to enhance the level of beneficial fatty acids in sheep milk. Small Rumin. Res., 59: 169-180

47. CRUZ-SUAREZ, L. E., RICQUE-MARIE, D., TAPIA-SALAZAR, M., MCCALLUM, I. M., HICKLING, D., (2001). Assessment of differently processed feed pea (Pisum sativum) meals and canola meal (Brassica sp.) in diets for blue shrimp (Litopenaeus stylirostris). Aquacul., 196(1-2): 87-104

48. AHMAD, M., KHAN, M. S. (2011). Toxicological assessment of selective pesticides towards plant growth promoting activities of phosphate solubilizing Pseudomonas aeruginosa. Act. Microb. Immun. Hung., 58: 169-187

49.KOZHOUHAROV, Y., LINGORSKI, V., (2012). Dynamics of forage biomass accumulation in decades of a natural meadow of agrostis capillaris-festuca fallax type in the rhodope mountains. Banat's J. Biotech., 3(5), 31-36 
50. BASHIR, H., KHAN, Z.I., AHMAD, K., ZAFAR, A., SOHAIL, M., IQBAL, M., MUNEEB, A., JAMIL, M., AHSAN, T., BABAR, Z. U., FATIMA, H., (2017). Proximate composition evaluation of wild forages in relation to requirement of grazing ruminants in a semi-arid environment of Punjab, Pakistan. Fresen. Environ. Bull., 26(5): 3138-3147

51. CASTELL, A.G., GUENTER, W. AND IGBASAN, F. A., (1996). Nutritive value of peas for nonruminant diets. Anim. Feed Sci. Tech., 60: 209-227

52. HUSSAIN, J., KHAN, A. L., REHMAN, N., ZAINULLAH, K. F., HUSSAIN, S. T., SHINWARI, Z. K., (2009). Proximate and nutrient investigations of selected medicinal plants species of Pakistan. Pak. J. Nut., 8: 620-624

53.BHATTACHARJEE, S., SULTANA, A., SAZZAD, M. H., ISLAM, M. A., AHTASHOM, M., ASADUZZAMAN, M., (2013). Analysis of the proximate composition and energy values of two varieties of onion (Allium cepa L.) bulbs of different origin: A comparative study. Int. J. Nut. Food Sci., 2(5): 246-253

54. JOHNSON, L. M., HARRISON, J. H., DAVIDSON, D., MAHANNA, W. C., SHINNERS, K., (2003). Corn silage management: Effects of hybrid, chop length, and mechanical processing on digestion and energy content. J. Dairy Sci., 86: 208-231

Manuscript received: 20.05 .2020 